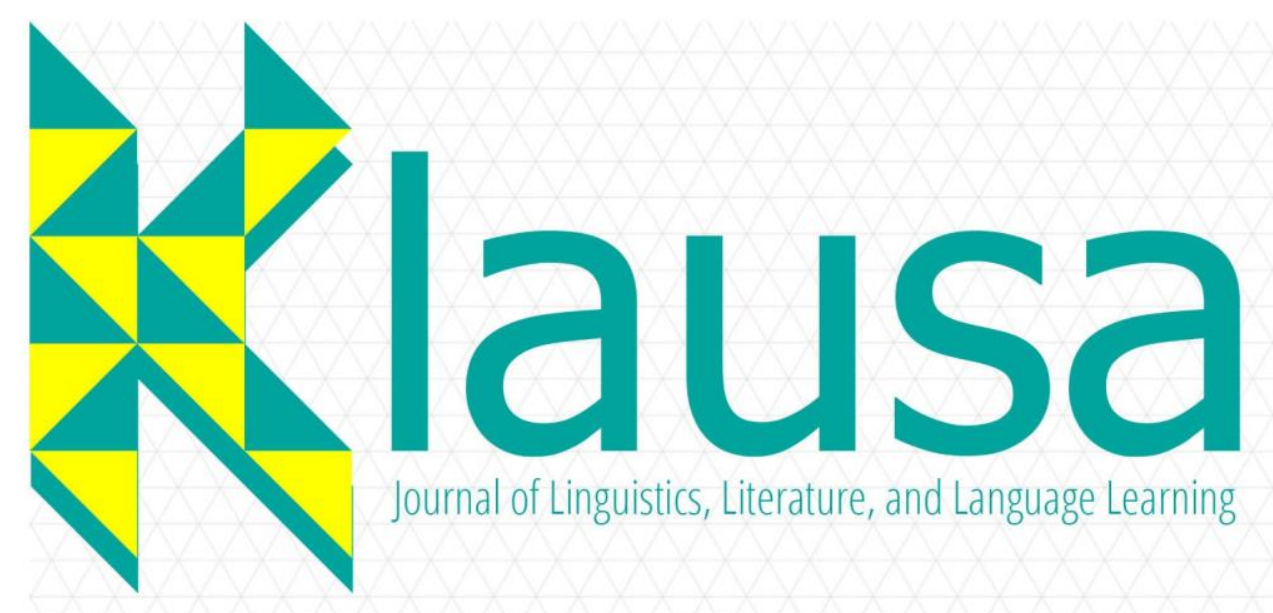

ISSN 2301-4822 Volume 03 Nomor 02 2019

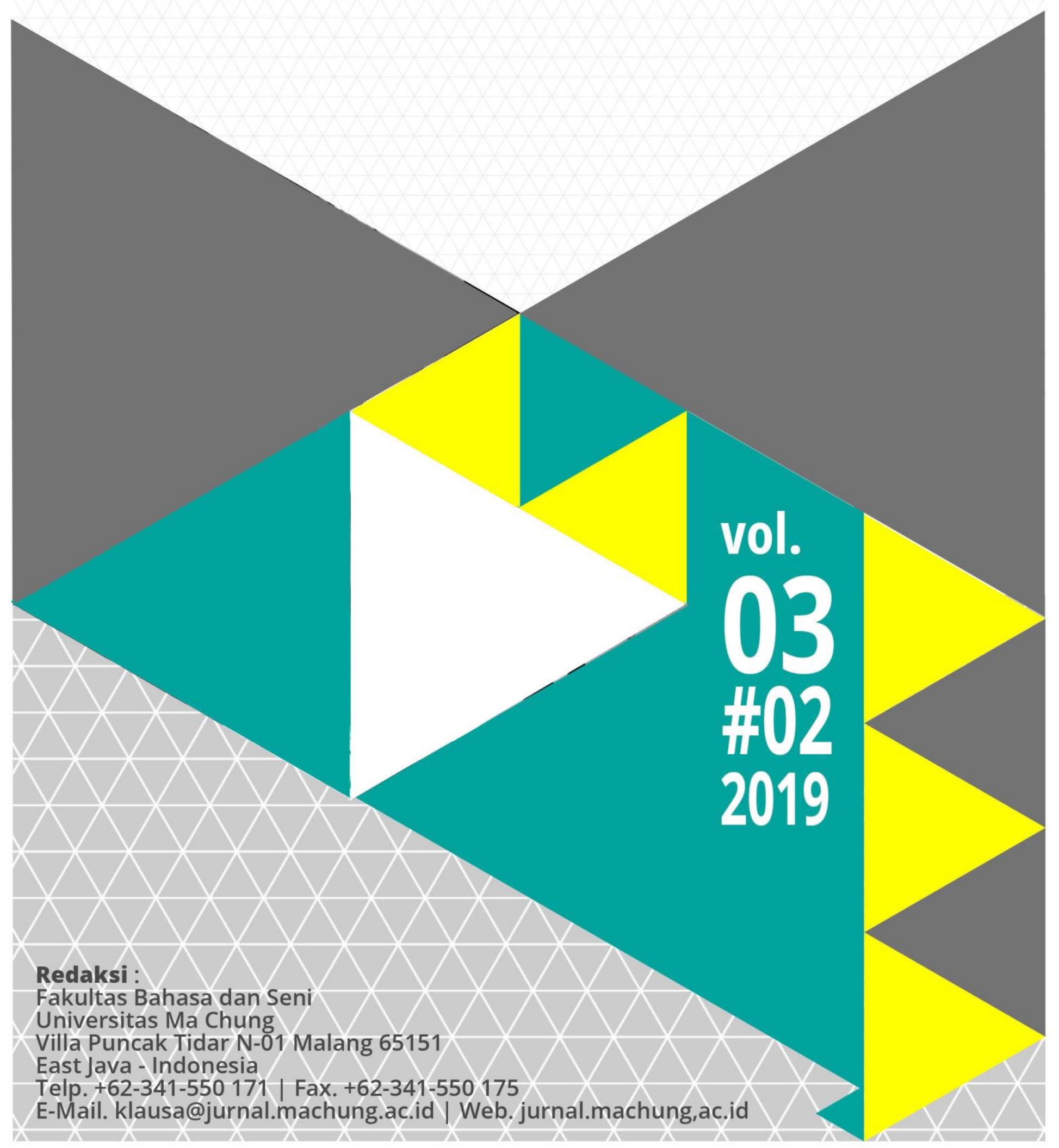


ISSN: $2301-4822(p)$

2620-9527 (e)

DOI: $\quad 10.33479 /$ klausa.v3i2

\section{$\forall A 9 \pi \cap 5$ Kajian Linguistik, Pembelajaran Bahasa, dan Sastra}

\section{Editorial Team}

Editor-in-Chief

Journal Manager

Editors

Reviewers

Publisher

Address

Frequency
: Dr. Daniel Ginting

: Wawan Eko Yulianto, Ph.D.

: Prof. Dr. Patrisius I. Djiwandono

Lilis Lestari Wilujeng, M.Hum.

: F.X Dono Sunardi, M.A.

Dhatu Sitaresmi, MTCSOL.

Anggrah Diah Arlinda, MTCSOL.

Prof. E Sadtono, Ph.D.

Yohanna Nirmalasari, S.Pd., M.Pd.

Prof. A. Effendi Kadarisman, Ph.D.

Sisilia Halim, Ph.D.

Dr. Mundi Rahayu

Dr. Ross Wood

Dr. Leticia Araceli Salas Serrano

: Faculty of Language and Arts

Universitsas Ma Chung

: The Faculty of Language and Arts

Ma Chung University

Villa Puncak Tidar N-01 (65151)

Malang, East Java, Indonesia

Email: jurnal.klausa@machung.ac.id

: Twice a year 


\section{CONTENTS}

CONTENTS

FOREWORD II

THE COPING BEHAVIOR IN BOOTH TARKINGTON'S THE

MAGNIFICENT AMBERSONS: AN INDIVIDUAL PSYCHOLOGICAL

APPROACH

Radityo Tri Nugroho

IMPROVING READING COMPREHENSION SKILL OF CIVIL

ENGINEERING STUDENTS THROUGH COLLABORATIVE

STRATEGY

Addy Utomo

KETERLAMBATAN BERBICARA PADA ANAK USIA 4 TAHUN

Anisa Norcholifah, Wahyu Oktavia

PENYUSUNAN LAMAN MENULIS BERITA UNTUK KEGIATAN

EKSTRAKURIKULER JURNALISTIK SMA

Ardi Wina Saputra

SOCIAL POWER: THE GAP BETWEEN MAJORITY AND MINORITY GROUPS IN MARTIN LUTHER KING JR.'S SPEECHES 


\title{
PENYUSUNAN LAMAN MENULIS BERITA UNTUK KEGIATAN EKSTRAKURIKULER JURNALISTIK SMA
}

\author{
Ardi Wina Saputra ${ }^{1}$ \\ ${ }^{1}$ Universitas Katolik Widya Mandala Madiun, c.ardi_7@yahoo.com
}

\begin{abstract}
This research aims to create a writing website as a media to coach extracurricular activity in journalism, especially in news story writing. The research applied a Research and Development Model in which date were collected through questionnaries and interviews with experts in media, materials, teachers, and students of extracurricular activities in journalism.
\end{abstract}

Key Terms: news writing website, extracurricular activity in journalism

\begin{abstract}
Penelitian ini bertujuan menghasilkan laman menulis berita sebagai wadah pembinaan kegiatan ekstrakurikuler jurnalistik, khususnya dalam bidang menulis berita. Rancangan penelitian yang digunakan adalah penilitian pengembangan model Research and Development (R\&D). Data dikumpulkan dengan menggunakan angket dan wawancara pada ahli media, ahli materi, dan guru serta siswa kegiatan ekstrakurikuler jurnalistik.
\end{abstract}

Key Terms: laman menulis berita, kegiatan ekstrakurikuler jurnalistik

\section{PENDAHULUAN}

Proses komputerisasi semakin berkembang cepat saat ini. Frey dan Osbroe (2013:1) meneliti 702 macam pekerjaan dan konsekuensinya untuk berganti karena proses komputerisasi. Berdasarkan jumlah tersebut, disimpulkan bahwa satu hingga dua dekade lagi akan banyak pekerjaan-pekerjaan baru yang muncul dan sekaligus mendegradasi posisi pekerjaan lama. Menurut Liem (2016:118), Amazon.com sudah memperkerjakan robot dengan pesanan 400 produk lebih per detik. Fakta-fakta tersebut menunjukkan bahwa komputerisasi, khususnya internet sudah tidak dapat lagi dihindarkan dari kehidupan siswa zaman sekarang. Dalam dunia pendidikan, tidak sedikit guru maupun siswa yang melakukaan proses belajar mengajar menggunakan internet. Bahkan, internet bukan lagi barang mewah yang bisa diakses di sekolah. Namun, internet juga dapat diakses di luar kelas hingga di rumah masing-masing. Sumber rujukan serta sumber belajar semakin banyak, sehingga siswa semakin kaya akan sumber pengetahuan dari berbagai media. Laksamana (2014:118) mengatakan bahwa Indonesia memiliki lebih dari 1.600 media baik cetak maupun elektronik yang dapat diakses oleh semua warga. Itulah sebabnya, perlu pembiasaan serta pemanfaatan secara optimal dalam mengatasi kemajuan teknologi dan informasi ini.

Kemajuan teknologi informasi dan komunikasi yang semakin marak tersebut membuat siswa zaman sekarang tergolong sebagai anak anak yang hidup dalam generasi Z . Menurut Tapscot (2008), anak-anak yang disebut generasi Z dilahirkan di era 1998 hingga 
tahun 2009. Anak-anak ini juga disebut sebagai anak-anak teknologi. Mereka disebut generasi $\mathrm{Z}$ karena saat mereka lahir, teknologi informasi dan komunikasi sedang berkembang dengan sangat cepat. Televisi, handphone, hingga komputer sudah ada saat anak-anak tersebut lahir. Hal ini tentu berbeda dengan generasi sebelumnya. Generasi yang lahir di bawah tahun 2000 mengalami perkembangan teknologi yang sangat lambat. Guru pengajar yang lahir juga dapat dipastikan lahir sebelum tahun 2000. Singh (2014) mengatakan bahwa generasi $\mathrm{Z}$ memiliki musuh lebih banyak daripada generasi sebelumnya. Hal tersebut karena generasi $\mathrm{Z}$ cenderung lebih individualistik. Oleh sebab itu, perlu pemahaman lebih untuk memahami generasi yang lahir di era 2000 atau generasi $Z$ ini.

Menanggapi fenomena generasi Z ini, Kasali (2017:235) dengan tegas menyebut fenomena ini sebagai Strawberry Generation. Dinamakan Strawberry Generation karena secara imajiner wujudnya seperti strawberri yaitu indah, menawan, tapi sekaligus mudah rapuh. Wujud yang indah tersebut karena hampir semua anak saat ini memiliki telepon pintar dan di dalam telepon pintar tersebut dilengkapi akses untuk menjangkau internet. Jaringan 3G hingga 4G semakin dipermudah dan terus menerus diperbaharui oleh pemerintah. Akses tersebut memudahkan siswa untuk mengunduh dan mencari berbagai informasi yang diinginkannya.

Dalam Kuliah Tamu Keguruan Bahasa Pascasarjana UM 2016, Dr. Gumawang Jati, M.A., menyampaikan empat karakteristik Generasi Z. Pertama, fasih dalam teknologi sehingga membuatnya cepat menguasai gawai terbaru. Kedua, memiliki rasa kesadaran interaksi sosial yang tinggi. Ketiga, ekspresif terhadap segala sesuatu yang ditangkap oleh inderanya. Keempat, sangat dinamis sehingga sering berpindah dengan cepat dari satu tempat ke tempat lain. Keempat karakter tersebut perlu diwadahi dalam sebuah media yang memampukan mereka untuk dapat menyalurkan hasratnya dengan cara yang lebih positif. Karakteristik tersebut seolah menunjukkan bahwa cara kerja mereka sebenarnya sama seperti cara kerja seorang jurnalis mencari berita.

Berita merupakan informasi yang disebarluaskan pada pembaca. Menurut Romli (2014:11), penyampaian berita di era modern ini cenderung dilakukan secara daring daripada cara-cara konvensional (cetak). Temuan Romli tersebut berdasarkan survey The Online News Association (2002) yang melaporkan bahwa berita daring sama kredibelnya dengan berita yang ditulis oleh media tradisional (Romli, 2014:37). Oleh sebab itu, diperlukan model media yang mampu mengajak siswa untuk terlibat aktif dalam kegiatan pemberitaan di media daring. Aktivitas memberitakan informasi di media daring disebut sebagai aktifitas jurnalisme warga atau reportase warga. Nugraha (2012:1) mengatakan bahwa sesungguhnya aktifitas ini merupakan aktifitas citizen reportage. Istilah itu dipilih karena menurut Pepih, menjadi wartawan harus diikat dengan kode etik jurnalistik tapi menjadi reporter atau pewarta tidak sedemikian ketat aturanya.

Melalui kegiatan reportase warga, siswa diajak proaktif untuk menjadi jurnalis dan memberitakan informasi yang diperoleh pada khalayak. Proses mengaktifkan siswa dalam kegiatan reportase warga ini juga merupakan salah satu wujud nyata mengajak siswa untuk belajar bahasa Indonesia. Salah satu keterampilan berbahasa adalah keterampilan menulis, dan salah satu genre penulisan yang dapat dikuasai siswa adalah menulis berita. Itulah sebabnya, cara yang dapat digunakan untuk meleburkan kemajuan teknologi informasi dengan kegiatan pembelajaran adalah menciptakan media yang dapat mewadahi siswa untuk 
menyalurkan bakat menulisnya melalui media daring, termasuk dalam kegiatan ekstrakurikuler.

Kegiatan ekstrakurikuler mengacu pada lampiran standar isi berdasarkan Peraturan Menteri Pendidikan Nasional No 22 tahun 2006. Dalam lampiran standar isi baik untuk tingkat SD, SMP, dan SMA dinyatakan bahwa struktur kurikulum terdiri atas tiga komponen, yaitu (1) komponen mata pelajaran, (2) muatan lokal, dan (3) pengembangan diri. Komponen pengembangan diri bukanlah mata pelajaran yang harus diasuh oleh guru. Pengembangan diri bertujuan memberikan kesempatan kepada peserta didik untuk mengembangkan dan mengekspresikan diri sesuai dengan kebutuhan, bakat, dan minat setiap peserta didik yang disesuaikan dengan kondisi sekolah. Kegiatan pengembangan diri difasilitasi atau dibimbing oleh konselor, guru, atau tenaga kependidikan yang dapat dilakukan dalam bentuk kegiatan ekstrakurikuler.

Berdasarkan studi pendahuluan yang dilakukan oleh peneliti, hampir semua sekolah SMA/MAN di Kota Malang memiliki kegiatan ekstrakurikuler jurnalistik. Sekolah yang peneliti amati di wilayah Malang Raya adalah SMA Negeri 5 Malang, MAN 3 Malang, SMA Katolik Santo Albertus Malang. Sedangkan sekolah yang peneliti amati di Kabupaten Malang adalah SMA An-Nur Bululawang. Berdasarkan hasil pengamatan tersebut diperoleh data bahwa sekolah-sekolah itu telah terkoneksi dengan jaringan internet, bahkan yang berlokasi di kabupaten sekalipun. Namun sayangnya koneksi tersebut belum dimanfaatkan secara optimal. Berdasarkan hasil penelitian awal yang dilakukan di sekolah-sekolah tersebut, diperoleh data bahwa kegiatan ekstrakurikuler jurnalistik sangat jarang sekali menggunakan fasilitas internet. Siswa peserta kegiatan ekstrakurikuler jurnalistik pun mengatakan bahwa selama kegiatan ekstra berlangsung, tidak ada bahan ajar baik konvensional maupun daring dalam kegiatan ekstrakurikuler jurnalistik. Siswa masih mengandalkan tuturan guru dalam memperoleh informasi mengenai jurnalistik.

Fasilitas akses internet kurang dimanfaatkan dengan baik oleh siswa. Selama ini siswa masih cenderung memainkan gawainya dan memanfaatkan fasilitas wifi yang diberikan oleh sekolah dengan cara yang kurang akademis, terlebih saat kegiatan ekstrakurikuler jurnalistik berlangsung. Berdasarkan fakta tersebut maka siswa perlu diberikan sumber belajar yang mampu dijangkau serta dipraktikan secara nyata oleh siswa selama kegiatan ekstrakurikuler berlangsung. Wujud sumber belajar tersebut adalah media daring.

Penelitian terdahulu yang juga memanfaatkan media daring sebagai media pembalajaran adalah penelitian dari Widyartono dengan judul Pengembangan Bahan Ajar Bahasa Indonesia dengan Web Interaktif (2010). Penelitian ini menghasilkan produk berupa laman bahan ajar Bahasa Indonesia. Semua materi yang berkaitan dengan Bahasa Indonesia disajikan dalam laman ini. Penelitian selanjutnya adalah penelitian yang dilakukan oleh Putera dengan judul Pengembangan Blog Pena Ilmiah Sebagai Media Menulis Artikel Ilmiah Bagi Guru (2015). Penelitian ini menghasilkan produk berupa blog yang membantu para guru untuk menulis artikel ilmiah. Kedua penelitian tersebut memang telah menghasilkan media daring yang menjadi rumpun pembelajaran Bahasa Indonesia. Namun, keduanya belum membahas tentang penulisan berita. Berdasarkan hal tersebut maka peneliti mengambil judul penelitian Penyusunan Laman Menulis Berita Bagi Peserta Ekstrakurikuler Jurnalistik SMA. Laman yang dihasilkan penulis nantinya membahas tentang cara cara menulis sekaligus memproduksi berita melalui media daring. 


\section{METODE PENELITIAN}

Metode penelitian ini adalah penelitian pengembangan. Model pengembangan laman menulis berita untuk kegiatan ekstrakurikuler jurnalistik adalah model yang diadaptasi dari model pengembangan dengan memodifikasi metode Research and Development $(R \& D)$ dari Sugiyono (2011:49). Langkah-langkah dalam model pengembangan ini yaitu (1) mengidentifikasi kebutuhan, (2) pengumpulan data, hingga (3) desain produk.

Pertama, potensi dan masalah. Dalam penelitian ini potensi dan masalah dilakukan dengan mengidentifikasi kebutuhan siswa. Mengidentifikasi kebutuhan merupakan proses yang dilakukan pengembang untuk mengidentifikasi serta menelaah kebutuhan. Pengembang melakukan analisis untuk memperoleh data. Kemudian, pengembang melakukan observasi dan wawancara dengan pembina ekstrakurikuler jurnalistik. Observasi dilakukan untuk melihat kondisi di lapangan, sedangkan wawancara dilakukan guna memperoleh informasi dari pembina dan peserta ekstrakurikuler jurnalistik.

Pengembang melakukan observasi secara langsung pada bulan Agustus 2017 dengan melihat proses pembinaan ekstrakurikuler jurnalistik di sekolah-sekolah yang nantinya dijadikan sebagai objek penelitian. Sekolah-sekolah tersebut antara lain adalah SMA Tazkiyah International School, SMA Katolik St. Albertus Malang (SMA Dempo), dan SMA Negeri 7 Malang. Sekolah-sekolah tersebut dipilih karena memiliki fasilitas internet yang belum digunakan secara maksimal dalam kegiatan pembinaan ekstra kuriuler jurnalistik. Hasil dari observasi juga menghasilkan temuan bahwa sekolah-sekolah tersebut juga memiliki fasilitas networking berupa Local Area Network (LAN), Wide Area Network (WAN), intranet, dan internet. Sayangnya, fasilitas tersebut belum dioptimalkan sepenuhnya dalam kegiatan ekstrakurikuler jurnalistik. Hal tersebut ditunjukkan dengan pembina yang selalu menggunakan metode tatap muka langsung. Inilah yang membuat kegiatan jurnalistik terasa membosankan bagi siswa yang dilahirkan di era generasi $\mathrm{Z}$.

Selain observasi, pengembang juga melakukan wawancara. Wawancara dilakukan pada pembina dan peserta ekstrakurikuler jurnalistik di sekolah-sekolah yang telah penulis pilih. Dari hasil wawancara yang dilakukan oleh pengembang sebelum penelitian, maka diperoleh data dan informasi bahwa kondisi kegiatan ekstrakurikuler jurnalistik di sekolahsekolah tersebut memerlukan adanya media pembinaan yang mampu menjadi fasilitas belajar peserta ekstrakurikuler jurnalistik yang inovatif untuk menjadikan mereka lebih tertarik lagi dalam kegiatan menulis berita.

Fasilitas ini nantinya juga menjadi sarana subtitusi memberikan materi bagi pembina, manakala pembina tersebut sedang sibuk atau berhalangan hadir ketika ekstrakurikuler berlangsung. Akses yang mudah juga diperlukan oleh peserta ekstrakurikuler jurnalistik ketika hendak belajar menulis berita. Lewat jaringan internet yang ada dalam perangkatnya, peserta dapat mengakses materi dimanapun dan kapanpun mereka mau. Oleh sebab itu, maka inovasi laman yang interaktif dan efektif dapat dikemas secara menarik dan sebaik mungkin agar mampu memantik semangat peserta ekstrakurikuler jurnalistik, sehingga meningkatkan kemampuan mereka dalam belajar menulis berita.

Kedua, pengumpulan data. Setelah kebutuhan diidentifikasi secara faktual, maka selanjutnya pengembang mengumpulkan data dalam bentuk informasi yang dapat digunakan sebagai bahan perencanaan produk. Pengumpulan data dilakukan pada bulan 
November 2016 dengan cara mengkaji tujuan dan manfaat pembinaan ekstrakurikuler jurnalistik. Pengembang juga mengumpulkan data yang terkait dengan materi untuk menulis berita hingga mempublikasi berita. Data yang diperoleh pengembang bersumber dari buku dan internet. Materi ini nantinya digunakan oleh pengembang dalam menyusun laman menulis berita dalam pembinaan ekstrakurikuler jurnalistik.

Ketiga, desain produk. Pengembang melakukan desain produk berdasarkan kebutuhan yang sudah diidentifikasi serta data yang telah diperoleh sebelumnya. Produk pembinaan ekstrakurikuler jurnalistik berupa laman yang berisi materi tentang menulis berita agar layak dimuat dalam majalah sekolah. Desain produk meliputi beberapa aspek, yaitu aspek tampilan, aspek isi, dan aspek kebahasaan. Aspek tampilan memperhatikan penampilan sampul, warna, gambar, menu, ukuran dan jenis huruf. Materi menulis berita disusun dalam aspek isi. Sedangkan aspek kebahasaan menitikberatkan pada kebakuan dan kemudahan bahasa yang digunakan.

\section{HASIL DAN PEMBAHASAN}

\section{Deskripsi Produk}

Penelitian dengan judul Penyusunan Laman Menulis Berita Untuk Kegiatan Ekstrakurikuler Jurnalistik Bagi Siswa SMA ini menghasilkan produk berupa laman. Laman dikemas secara daring serta interaktif, komunikatif, dan inovatif. Di dalamnya berisi materi dan tips menulis berita, dan dilengkapi dengan contoh-contohnya. Pembina ekstrakurikuler jurnalistik nantinya hanya tinggal mengarahkan saja siswanya untuk aktif menulis berita melalui media yang telah disediakan. Laman dibuat secara daring sehingga dapat diakses kapanpun dan dimanapun asalkan terhubung dengan koneksi internet. Laman dapat diakses melalui gawai (komputer, laptop, smartphone, tab, dan gawai lainya) yang terkoneksi dengan jaringan internet.

Laman menulis berita memiliki berbagai macam menu yang membantu siswa untuk lebih produktif dalam menulis berita. Pada dasarnya, spesifikasi produk dibagi menjadi empat aspek utama, yaitu (1) tampilan, (2) isi, (3) kebahasaan, dan (4) kinerja. Semua itu terintegrasi dalam sebuah domain laman yang diharapkan mampu mempermudah pembelajaran menulis berita pada kegiatan ekstrakurikuler jurnalistik.

\section{Wujud Laman}

Spesifikasi produk yang diharapkan dalam penyusunan laman dijelaskan melalui aspek materi dan tampilan. Materi dimulai dengan pengenalan jurnalistik serta motivasi yang diberikan pada siswa terkait dengan dunia jurnalistik. Setelah siswa termotivasi, langkah selanjutnya adalah memahami berita. Langkah ini menggiring siswa untuk mulai membaca berita hingga mengenal unsur unsur berita. Materi terakhir adalah materi tentang peliputan berita. Pada materi ini, siswa diajak untuk mulai meliput berita. Materi ini juga membantu siswa untuk memilih berita, mencari narasumber, melakukan wawancara, hingga mengolah informasi untuk dijadikan sebuah berita yang utuh.

Aspek tampilan dalam laman juga tidak kalah pentingnya. Tampilan harus didesain semenarik mungkin. Tampilan laman mengintegrasikan secara daring gabungan teks, gambar, dan animasi, sehingga semakin memudahkan siswa untuk memahami materi yang disajikan. Tujuan dari desain tampilan adalah untuk memudahkan siswa memahami materi yang 
disajikan. Selain itu, tampilan juga berfungsi untuk menarik perhatian siswa agar mau belajar jurnalistik. Secara garis besar, sistematika produk yang telah diuraikan dapat diringkas sebagai berikut.

Tabel 1.1 Spesifikasi Produk Laman Menulis Berita sebagai Media Pembinaan Kegiatan Ekstrakurikuler Jurnalistik pada Aspek Tampilan/ Format.

\section{TAMPILAN/}

FORMAT

\begin{tabular}{|c|c|c|}
\hline Subbagian & Spesifikasi & Tujuan \\
\hline Cover/ Sampul & \begin{tabular}{l}
\multicolumn{2}{c}{ Menggambarkan } \\
tujuan laman dan nama \\
laman disertai ketentuan \\
untuk mengaksesnya
\end{tabular} & $\begin{array}{l}\text { Memberikan informasi } \\
\text { tentang identitas, tujuan, serta } \\
\text { apa yang diharapkan dengan } \\
\text { dibuatnya laman ini. }\end{array}$ \\
\hline Menu & $\begin{array}{l}\text { Bertujuan untuk } \\
\text { memilih dan menentukan } \\
\text { fitur-fitur yang hendak } \\
\text { dipilih siswa }\end{array}$ & $\begin{array}{l}\text { Menu yang disusun } \\
\text { dibuat untuk menggiring siswa } \\
\text { agar mampu menulis berita } \\
\text { sendiri }\end{array}$ \\
\hline Font & $\begin{array}{l}\text { Font yang } \\
\text { digunakan adalah Comic } \\
\text { Sans dengan mengambil } \\
\text { ukuran font yakni } 12 \text { serta } \\
\text { menggunakan font color } \\
\text { berwarna warni sesuai } \\
\text { latar setiap laman }\end{array}$ & $\begin{array}{l}\text { Mengambil jenis, } \\
\text { ukuran, serta ukuran huruf } \\
\text { Comic Sans dimaksudkan untuk } \\
\text { menampilkan informasi melalui } \\
\text { bentuk tulisan yang tidak } \\
\text { terkesan kaku namun tetap } \\
\text { komunikatif, sesuai dengan } \\
\text { kaidah jurnalistik. }\end{array}$ \\
\hline $\begin{array}{c}\text { Pemilihan } \\
\text { warna background }\end{array}$ & $\begin{array}{l}\text { Warna yang } \\
\text { digunakan beragam sesuai } \\
\text { dengan dunia remaja yang } \\
\text { dinamis. }\end{array}$ & $\begin{array}{l}\text { Keberagaman warna ini } \\
\text { dipilih karena remaja sangat } \\
\text { dinamis dalam berkarya. }\end{array}$ \\
\hline $\begin{array}{l}\text { Gambar/ } \\
\text { Animasi }\end{array}$ & \begin{tabular}{l}
\multicolumn{2}{c}{ Menggunakan } \\
gambar manusia, hewan, \\
tumbuhan, benda, maupun \\
pemandangan yang \\
mendukung isi laman.
\end{tabular} & $\begin{array}{l}\text { Meyakinkan siswa } \\
\text { tentang fakta yang terjadi } \\
\text { dalam pemberitaan di laman ini } \\
\text { serta sebagai ilustrasi yang } \\
\text { mendukung pesan berita agar } \\
\text { sampai pada pembaca. }\end{array}$ \\
\hline
\end{tabular}


Tabel 1.2 Spesifikasi Produk Laman Menulis Berita Sebagai Media Pembinaan Kegiatan Ekstrakurikuler Jurnalistik pada Aspek Isi.

\begin{tabular}{|c|c|c|}
\hline \multicolumn{3}{|c|}{ ISI } \\
\hline Aspek & Spesifikasi & Tujuan \\
\hline Jurnalistik & \begin{tabular}{l}
\multicolumn{4}{c}{ Menu jurnalistik ini } \\
berisi mengenai pengenalan \\
jurnalistik sekaligus motivasi \\
pada siswa untuk mau ikut \\
serta dalam dunia jurnalistik. \\
Menu ini dibagi menjadi \\
empat yaitu (1) serunya \\
jurnalistik, (2) $\quad$ jurnalis \\
Indonesia, (3) dari jurnalis \\
hingga news anchor, serta (4) \\
sastrawan dan jurnalisme.
\end{tabular} & $\begin{array}{l}\text { iswa mendapat motivasi untuk } \\
\text { mengikuti kegiatan } \\
\text { ekstrakurikuler jurnalistik. }\end{array}$ \\
\hline $\begin{array}{l}\text { Memahami } \\
\text { Berita }\end{array}$ & $\begin{array}{l}\text { Menu memahami } \\
\text { berita merupakan menu yang } \\
\text { berisi tentang pemahaman } \\
\text { terhadap berita. Pada menu } \\
\text { ini, siswa diajak untuk } \\
\text { memahami serta membedah } \\
\text { bersama isi berita. Menu ini } \\
\text { dibagi menjadi tiga yaitu (1) } \\
\text { membaca berita, (2) } \\
\text { mengenali struktur berita, dan } \\
\text { (3) mendalami struktur teks } \\
\text { berita. }\end{array}$ & $\begin{array}{l}\text { iswa diajak untuk memahami } \\
\text { berita dengan cara membaca, } \\
\text { mengenali, hingga mendalami } \\
\text { struktur berita tersebut. }\end{array}$ \\
\hline Mulai Meliput & $\begin{array}{l}\text { Menu ini bertujuan untuk } \\
\text { mengajak siswa melakukan } \\
\text { kegiatan peliputan jurnalistik yang } \\
\text { terstruktur tahap demi tahap. Oleh } \\
\text { sebab itu, menu ini dibagi menjadi } \\
\text { enam yaitu (1) pilih tema beritamu, } \\
\text { (2) latihan pilih topik, (3) buat } \\
\text { rancangan leadnya, (4) pilih sumber } \\
\text { beritamu, (5) menggali informasi, } \\
\text { dan (6) mengolah informasi. }\end{array}$ & $\begin{array}{l}\text { iswa diajak untuk praktik } \\
\text { meliput berita di lapangan dan } \\
\text { menyelesaikan tahap demi } \\
\text { tahapnya sesuai dengan } \\
\text { tagihan yang harus dikerjakan } \\
\text { dalam laman. }\end{array}$ \\
\hline
\end{tabular}


Tabel 1.3 Spesifikasi Produk Laman Menulis Berita Sebagai Media Pembinaan Siswa dalam Kegiatan Ekstrakurikuler Jurnalistik pada Aspek Kebahasaan.

\begin{tabular}{|c|c|c|}
\hline \multicolumn{3}{|c|}{ KEBAHASAAN } \\
\hline Aspek & Spesifikasi & Tujuan \\
\hline \multirow[t]{2}{*}{ Kemudahan } & Bahasa & Siswa \\
\hline & $\begin{array}{l}\text { digunakan komunikatif, } \\
\text { singkat, padat, dan jelas } \\
\text { sehingga mudah dimengerti } \\
\text { oleh siswa. }\end{array}$ & $\begin{array}{l}\text { memahami pemberitaan dan } \\
\text { memperoleh informasi yang } \\
\text { dibutuhkan. }\end{array}$ \\
\hline Kebakuan & $\begin{array}{l}\text { Sesuai dengan ejaan } \\
\text { yang disempurnakan serta } \\
\text { kaidah penulisan berita. }\end{array}$ & $\begin{array}{l}\text { Siswa dapat menuliskan } \\
\text { setiap unsur beritanya sesuai } \\
\text { dengan tatacara penulisan } \\
\text { berita yang benar. }\end{array}$ \\
\hline
\end{tabular}

\section{KESIMPULAN}

Proses digitalisasi di berbagai bidang sudah tidak dapat dihindari lagi, termasuk bidang pendidikan. Oleh sebab itu diperlukan inovasi dalam pembelajaran baik dalam segi kurikuler maupun ekstrakurikuler. Penelitian ini menghasilkan produk berupa laman untuk kegiatan ekstrakurikuler jurnalistik SMA. Berdasarkan studi pendahuluan yang telah dilakukan oleh peneliti, ditemukan bahwa hampir semua sekolah memiliki akses internet tetapi sangat jarang dimanfaatka dalam kegiatan pembelajaran. Khsususnya ekstrakurikurel jurnalistik. Hampir setiap sekolah di wilayah Malang raya juga memiliki kegiatan ekstrakurikuler jurnalistik dan produk jurnalistik mulai dari buletin hingga majalah. Berdasarkan temuan-temuan tersebut maka laman yang dihasilkan dapat menjadi sarana pembelajaran siswa dan guru dalam mengembangkan kegiatan ekstrakurikuler jurnalistik di sekolah.

Manfaat pengembangan laman menulis berita sebagai media pembinaan ekstrakurikuler jurnalistik SMA adalah memberikan wadah bagi siswa yang didominasi generasi $\mathrm{Z}$ untuk mengoptimalkan pembelajaran melalui gawai dan internet yang semakin mudah diakses oleh siswa.

Bagi pembina adalah untuk memberikan sebuah alternatif baru dalam pembinaan jurnalistik yang sesuai dengan kondisi siswa zaman sekarang. Alternatif tersebut tentunya lebih canggih dan mudah diakses oleh siswa dan guru sehingga guru dapat melakukan pembinaan serta kontrol melalui laman yang tidak dibatasi oleh ruang dan waktu.

Bagi masyarakat adalah untuk memberikan referensi baru di bidang jurnalistik tentang laman yang dapat dijadikan sumber belajar atau referensi belajar dalam menulis berita. Masyarakat yang dimaksud dalam bagian ini adalah para pegiat literasi dan masyarakat yang peduli terhadap kegiatan jurnalistik. Masyarakat juga dapat menyebarluaskan konten laman ini secara viral agar semakin bermanfaat bagi sesama.

\section{REFERENCES}

Frey, C. B., \& Osborne, M. A. (2017). The future of employment: How susceptible are jobs to computerisation?. Technological forecasting and social change, 114, 254-280. 
Kasali, R. (2017). Strawberry generation, anak-anak kita berhak keluar dari perangkap yang bisa membuat mereka rapuh. Bandung: Penerbit Mizan.

Laksamana, A. (2015). What CEO wants from PR. Bentang B first.

Liem, I. (2016). Majors for the Future. Jakarta: Grasindo.

Nugraha, P. (2012). Citizen Journalism: Pandangan, Pemahaman, dan Pengalaman. Jakarta: Kompas.

Putera, ZF. (2015). Pengembangan Blog Pena Ilmiah sebagai Media Pelatihan Menulis Artikel Ilmiah Bagi Guru. (Thesis, Universitas Negeri Malang).

Romli, AS. (2014). Jurnalistik Online: Panduan Praktis Mengelola Media Online. Bandung: Nuansa.

Singh, A. (2014). Challenges and issues of Generation Z. IOSR Journal of Business and Management, 16(7), 59-63.

Sugiyono. (2011). Metode Penelitian Pendidikan. Bandung: Alfabeta.

Taspcott, D. (2008). Grown Up Digital: How the Net Generation is Changing Your World. McGraw-Hill.

Widyartono, Didin. (2010). Pengembangan Bahan Ajar Bahasa Indonesia dengan Web Interaktif. (Thesis, Universitas Negeri Malang) 